\title{
FURTHER OBSERVATIONS ON THE TERM 'SEED' IN GENESIS
}

\author{
T. Desmond Alexander
}

In a recent study relating to Genesis 3:15, Jack Collins observes that certain syntactical features make it possible to distinguish between זֶר meaning 'seed' (singular) and 'seeds' (plural).1 This is important because the noun זִ i itself does not have distinctive singular and plural forms; the singular form זר also functions as a collective noun. After surveying all the occurrences of זררע meaning 'offspring' in the Hebrew Bible, Collins concludes that when a writer wishes to indicate that 'denotes a specific descendant, it appears with singular verb inflections, adjectives, and pronouns' ${ }^{2}$ On this basis the 'seed of the woman' in Genesis 3:15 must be understood as referring to a single individual and not numerous descendants.

There are, however, two texts within the book of Genesis which Collins fails to discuss adequately: 22:17-18a and 24:60. Both are taken by Collins to be examples of passages in which זְר must be understood as having a collective meaning. ${ }^{3}$ At first sight this appears correct. Genesis 22:17a speaks of Abraham's 'seed' becoming as numerous 'as the stars of heaven and as the sand that is on the seashore' (NRSV). Similarly, in Genesis 24:60a Rebekah's closest relatives bless her with the words, 'May you, our sister, become thousands of myriads'. In both passages the reference to many descendants is then immediately followed by similar, but not quite identical, phrases. Genesis 22:17b reads:

\footnotetext{
1'A Syntactical Note (Genesis 3:15): Is the Woman's Seed Singular or Plural?' TynB 48.1 (1997) 139-48.

2Ibid., 144.

3Ibid., 142.
} 


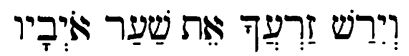

With minor variations this is echoed in Genesis 24:60b:

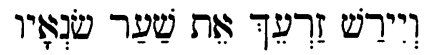

Both of these passages are usually understood as referring to 'posterity' in the plural. Thus, the NRSV translation of the final clause of Genesis 22:17 reads: 'and your [Abraham's] offspring shall possess the gate of their enemies' (emphasis added). A similar rendering is adopted for Genesis 24:60: 'may your [Rebekah's] offspring gain possession of the gates (sic.) of their foes' (NRSV; emphasis added). If Collins' thesis is correct, however, in both these cases זר ו ought to be understood as referring to a single individual and not many descendants; in each clause זִ זררע is the subject of a singular verb and the direct object is qualified by a singular possessive pronoun which refers back to ז?

Two possibilities arise in the light of these observations. Either Collins' approach is seriously flawed and it is not possible, using syntactic considerations, to distinguish clearly between the singular and collective uses of requires that scholars re-evaluate the ways in which Genesis 22:17-18a and 24:60 have normally been understood. While the former possibility is the easier option to adopt-in effect maintaining the status quo -there are other factors which suggest that it may be appropriate to re-examine the usual interpretation of these two passages.

A careful consideration of the divine speech in Genesis 22:16-18 reveals that the final clause of 22:17 appears to be set apart from what proceeds. The entire verse reads:

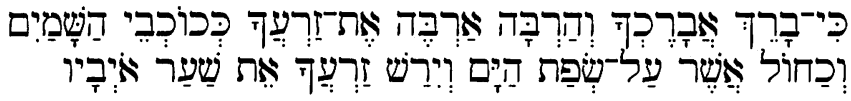

For I will surely bless you and increase your offspring like the stars of the heavens and like the sand on the sea- 
shore. And your offspring will possess the gate of his/ their enemies.

A striking feature of the final clause is the way in which it does not begin with a vav-consecutive; rather it is introduced by the imperfect verb שר?.: preceded by a non-converting 1. This syntactical arrangement leaves open the possibility that the referred to in the final clause differs from that mentioned in the first part of the verse. Whereas the first זֶר obviously refers to a very large number of descendants, the second would, following Collins' approach, denote a single individual who is victorious over his enemies.

This latter reading of 22:17 has implications also for

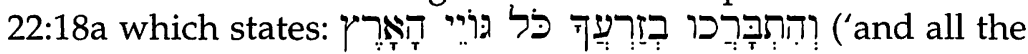
nations of the earth will be blessed through your offspring'). If the immediately preceding reference to 'seed' in 22:17 denotes an individual, this must also be the case in $22: 18 \mathrm{a}$, for there is nothing here to indicate a change in number. The blessing of 'all the nations of the earth' is thus associated with a particular descendant of Abraham, rather than with all those descended from him.

When we look outside of Genesis for allusions to 22:17b-18a, only one appears to exist. This comes in Psalm 72:17

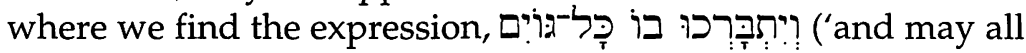
nations be blessed through him'). From the content of Psalm 72 it is clear that the individual mentioned here, through whom all nations shall be blessed, is a royal figure. While the psalm's title associates it with Solomon, its contents clearly envisages a king whose reign surpasses by far that of Solomon. Indeed, this future monarch is described as ruling the entire earth, bringing deliverance to the oppressed by defeating their enemies ( $c f$. Ps. 72:4-14).

The similarity between Genesis 22:18a and Psalm $72: 17 \mathrm{~b}$ is striking and supports the idea that the 'seed' mentioned in Genesis 22:17b-18a does not refer to all Abraham's descendants, but rather to a single individual. While Genesis 22 does not directly indicate that this 'seed' will be of royal standing, it is noteworthy that Genesis 17 anticipates that kings will come from Abraham and Sarah 
through Isaac (Gn. 17:6, 16). This divine promise is later repeated to Jacob (Gn. 35:11).

This interpretation of Genesis 22:17-18a fits well with the idea that the entire book of Genesis is especially interested in highlighting the existence of a unique line of male descendants which will eventually give rise to a royal dynasty. 4 This family line begins with Adam and is traced via his thirdborn son Seth to Noah (Gn. 5:1-32). The lineage then proceeds through Noah's son Shem to Abraham (Gn. 11:10-26). The line of descent moves next to Isaac and then to Jacob. While Jacob has twelve sons, special attention is given to his sons Joseph and Judah. Although Joseph, Jacob's eleventh-born son, dominates the concluding chapters of Genesis, and is obviously privileged, attention is also drawn to the 'seed' of Judah, Jacob's fourth-born son (Gn. 38:1-30). ${ }^{5}$ By the end of Genesis, the expectation is created that the principal line of descent will continue through Judah's son Perez and give rise to a royal dynasty (Gn. 49:8-12). ${ }^{6}$ Although Genesis does not trace the continuation of this line beyond Perez, the books of Ruth and Samuel associate it with David and his dynastic line.

As regards Genesis 24:60, the blessing pronounced on Rebekah has probably been influenced by the divine oath in Genesis 22:17-18; the similarities between them may be due to Abraham's servant recounting Yahweh's oath to Rebekah's family. Since Rebekah is travelling to Canaan to marry Isaac, it

${ }^{4}$ Cf. T.D. Alexander, 'From Adam to Judah: the Significance of the Family Tree in Genesis,' EQ 61 (1989) 5-19; idem, 'Genealogies, Seed and the Compositional Unity of Genesis,' TynB 44.2 (1993) 255-70.

${ }^{5}$ This distinction between Joseph and Judah is mentioned in 1 Ch. 5:1-2 in a short comment relating to Reuben, Jacob's first born son:

He (Reuben) was the firstborn, but when he defiled his father's marriage bed, his rights as firstborn were given to the sons of Joseph son of Israel; so he could not be listed in the genealogical record in accordance with his birthright, and though Judah was the strongest of his brothers and a ruler came from him, the rights of the firstborn belonged to Joseph.

${ }^{6}$ For a fuller discussion of Gn. 49:8-12, see T.D. Alexander, 'Messianic Ideology in the Book of Genesis', in P.E. Satterthwaite, R.S. Hess and G.J. Wenham (eds.), The Lord's Anointed: Interpretation of Old Testament Messianic Texts (Grand Rapids/Carlisle: Baker/Paternoster, 1995) 19-39, esp. 32-37. 
is quite appropriate that her relatives might send her away with the two-fold blessing that she should increase greatly and have a descendant who would defeat his enemies. In this way they acknowledge the importance of the role which Rebekah will play in the fulfilment of God's purposes for all humanity.

From the preceding discussion it is apparent that Collins' observations regarding the use of the term ז in Genesis 3:15 have implications also for the interpretation of Genesis 22:17-18 and 24:60. Of significance is the fact that these passages form part of a much larger picture in Genesis which centres around a unique line of descendants. The book of Genesis not only intimates that this lineage will eventually give rise to a royal dynasty, but also anticipates that a future member of this line will conquer his enemies and mediate God's blessing to the nations of the earth. Such expectations are clearly important for appreciating how the book of Genesis contributes to the NT understanding of Jesus Christ. 